\title{
Trophic Classification OF SElECTEd LAKES IN Yellowstone National PARK
}

\author{
A. WOODRUFF MILLER $\downarrow$ DAVID H. SNOW \\ CIVIL \& ENVIRONMENTAL ENGINEERING \\ BRIGHAM YOUNG UNIVERSITY $\uparrow \mathrm{PROVO} \uparrow \mathrm{UT}$
}

\section{$\uparrow \quad$ EXECUTIVE SUMMARY}

The purpose of this study is to evaluate the trophic state of five lakes in southern Yellowstone National Park in order to determine if the human activity in the local area is having a negative environmental impact and possibly increasing the eutrophication rate. While some previous analyses have been done on these lakes, this study is intended to be a preliminary trophic state evaluation to which future analyses can be compared.

The five lakes sampled are Shoshone Lake, Lewis Lake, Heart Lake, Riddle Lake, and Duck Lake. Each lake, with the exceptions of Riddle Lake and Duck Lake, was sampled at several locations. These samples were taken during the months of June through August of 1999 by Woodruff Miller and Dave Anderson of the BYU Civil \& Environmental Engineering Department.

The Carlson Trophic State Index, the Vollenweider Model, and the Larsen-Mercier Model were used to determine the trophic state of the lakes at each sampling location. The laboratory results were plotted on the applicable model. The Carlson Model requires measurements of the total phosphorus concentration, total chlorophyll-a concentration, and transparency. The Vollenweider Model requires the total inflowing phosphorus concentration and the hydraulic residence time. Finally, the LarsenMercier Model utilizes the mean inflowing phosphorus concentration and a phosphorus retention coefficient. (See the Models section of the complete report for further explanations.)

As would be expected, the trophic state of the lakes varied from month to month. Generally the lakes bordered between the oligotrophic and mesotrophic states. Shoshone Lake is classified as slightly oligotrophic while Lewis Lake and Heart Lake are classified as slightly mesotrophic. Riddle Lake is classified as mesotrophic and Duck Lake borders on the slightly oligotrophic and slightly mesotrophic state classification. The results are summarized in the table given below.

Nitrogen was also measured in the samples so as to determine the nitrogen-phosphorus ratio (N:P ratio) in the lakes. This was done to determine if nitrogen or phosphorus was the limiting nutrient in algal growth. Every sample from all five lakes is phosphorus limited except the August sample of Shoshone Lake at DeLacy Creek (northeast side) and the July sample of Lewis Lake at Lewis River (middle north side).

This trophic state evaluation is meant to be a preliminary study to which future studies can be compared. Further sampling of the lakes and tributaries at different times and different locations will be necessary in the future. Complete 40 page reports of these trophic state classifications have been sent to the Yellowstone Center for Resources at Mammoth and to the Snake Ranger District at the South Entrance. 
The chlorophyll-a analyses were conducted at the Pacific Northwest Regional Laboratories of the Bureau of Reclamation in Boise, Idaho. We wish to express our thanks to them for their gratuitous work and contribution to this project. We also wish to thank the Utah State Health Department, Division of Laboratory Services for partially supporting the analyses of the samples. Finally, we appreciate the interest and financial contribution from the Yellowstone Center for Resources who partially supported this research project in conjunction with the Brigham Young University Civil and Environmental Engineering Department.

Summary of Trophic Classifications of Sampling Sites

\begin{tabular}{|c|c|}
\hline Location & Classification \\
\hline $\begin{array}{l}\text { Shoshone Lake } \\
\text { DeLacy Creek (Northeast Side) } \\
\text { Shoshone Creek (West Side) } \\
\text { Near Outlet (Southeast Side) } \\
\text { Shoshone Lake Average }\end{array}$ & $\begin{array}{l}\text { Mesotrophic } \\
\text { Slightly Oligotrophic } \\
\text { Border of Oligotrophic \& Mesotrophic } \\
\text { Slightly Oligotrophic }\end{array}$ \\
\hline $\begin{array}{l}\text { Lewis Lake } \\
\text { Dogshead Creek (Northeast Side) } \\
\text { Lewis River (Middle North Side) } \\
\text { Boat Dock Near Outlet (South Side) } \\
\text { Lewis Lake Average }\end{array}$ & $\begin{array}{l}\text { Mesotrophic } \\
\text { Slightly Mesotrophic } \\
\text { Border of Oligotrophic \& Mesotrophic } \\
\text { Slightly Mesotrophic }\end{array}$ \\
\hline $\begin{array}{l}\text { Heart Lake } \\
\qquad \text { Witch Creek (Northwest Side) } \\
\text { Witch Creek (Southwest Side) } \\
\text { Heart Lake Average }\end{array}$ & $\begin{array}{l}\text { Slightly Oligotrophic } \\
\text { Slightly Mesotrophic } \\
\text { Slightly Mesotrophic }\end{array}$ \\
\hline $\begin{array}{l}\text { Riddle Lake } \\
\text { North Side }\end{array}$ & Mesotrophic \\
\hline $\begin{array}{l}\text { Duck Lake } \\
\text { East Side }\end{array}$ & Border of Oligotrophic \& Mesotrophic \\
\hline
\end{tabular}

